\section{José Rovira Collado}

Profesor Ayudante del área de Didáctica de la Lengua y la Literatura en la Universidad de Alicante. Doctor por la misma universidad con la investigación Literatura infantil $y$ juvenil en Internet: de la Cervantes Virtual a la LIJ 2.0. Ha sido lector de español en las Universidades de Nápoles y Salerno. Tiene más de cincuenta publicaciones dedicadas a la LIJ, la enseñanza del Español como lengua extranjera (ELE), la tecnología en el aula de lengua y literatura, las aplicaciones didácticas del cómic y literatura hispanoamericana.

Joan Miquel Rovira Collado Licenciado en Historia por la Universidad de Alicante es Técnico en el Consell de la Joventut d'Alacant, especialista en temas de coeducación, animación sociocultural y participación juvenil. Socio fundador $\mathrm{y}$ secretario técnico de Unicómic, las Jornadas del Cómic de la Universidad de Alicante que en 2016 cumplen diecinueve años. Ha realizado distintas investigaciones en torno al cómic como «La figura de la mujer en El jueves», «Cómic y espacio urbano» o «Evolución de la mujer en el cómic».
La figura del gaucho en la historieta argentina. De las versiones del Martín Fierro a Inodoro Pereyra J. MIQUEL ROVIRA-COLLADO

\title{
La figura del gaucho en la historieta argentina. De las versiones del Martín Fierro a Inodoro Pereyra
}

\author{
JOSÉ ROVIRA-COLLADO \\ Universidad de Alicante \\ JOAN MIQUEL ROVIRA-COLLADO \\ Unicómic
}

\section{RESUMEN}

Entre los múltiples personajes propios de la literatura latinoamericana, posiblemente el gaucho argentino ha sido el que ha despertado un mayor interés por la creación literaria, con el Martín Fierro de José Hernández como buque insignia de una amplia tradición. Esta se ve recogida muy pronto por la narración gráfica, ya sea a través de las ilustraciones de las ediciones clásicas, o en las adaptaciones de las grandes obras en revistas de historietas. Todas ellas van configurando una iconografía que completa el imaginario de los guachos, fundamental para la identidad argentina. En el siguiente trabajo haremos una panorámica de las historietas de gauchos desde las revistas tradicionales, las adaptaciones de obras literarias, como las del Martín Fierro, hasta personajes propios como Lindor Covas o Inodoro Pereyra.

Palabras Clave: Cómic, Historietas, Gauchos, Martín Fierro, Inodoro Pereyra.

\section{ABSTRACT}

Among the many own figures in Latin American literature, possibly the argentine Gaucho has been awakened greater interest in literary creation, with the Martin Fierro by José Hernández as the flagship of a long tradition. This tradition is very early adapted in the graphic narrative, either through illustrations of classical editions or adaptations of great works in comic books. All of them are setting an iconography that completes the imagine of the gauchos, fundamental in Argentina identity. In this paper we will analyzed cartoons gauchos from traditional magazines, adaptations of literary works, such as the Martin Fierro, to own characters as Lindor Covas or Inodoro Pereyra.

Keywords: Comic, Comic Books, Gauchos, Martin Fierro, Inodoro Pereyra.

\section{Introducción}

Si consideramos a la figura del Gaucho como un eje central en la conformación de la literatura argentina, no debemos negar la relevancia que han tenido las historietas en la configuración del imaginario de dicho país. Autores como Quino, Alberto Breccia o Héctor Germán Oesterheld, por solo citar a tres figuras, con muy distintas producciones, son reconocidos como referentes internacionales de la narración gráfica e iconos culturales de su país. En el siguiente trabajo haremos una revisión de las principales obras que plasman la figura del gaucho a través de historietas. 
$\mathrm{Al}$ igual que en la literatura argentina, el gaucho se convierte en un recurso argumental para la historieta que trata de reflejarnos las vivencias y peripecias de estos personajes, en unas ocasiones con un afán nacionalista de ensalzar algunos de sus elementos más característicos como reflejo de la propia historia argentina, en otras como un mero recurso para situar geográficamente y desarrollar o adaptar otras historias más cercanas al western norteamericano o de temática de aventuras. En este sentido, las adaptaciones y aportaciones de las historietas de gauchos sirven para ampliar la difusión y el reconocimiento de un elemento identitario fundamental para Argentina.

En esta investigación, después de presentar algunos de los ejemplos más significativos de las historietas de gauchos, pasaremos a las distintas ediciones del Martín Fierro como obra central del género. A continuación se hace una comparación con la obra de Roberto Fontanarrosa, Inodoro Pereyra, el gaucho más conocido en la Argentina contemporánea que desde una perspectiva cómica ayuda a la reconstrucción del género y propiciará la aparición de otras obras que tienen al gaucho como protagonista.

\section{Narración gráfica, LIJ y viñetas}

Antes de continuar es imprescindible hacer algunas anotaciones terminológicas y sobre las características de las obras presentadas. En primer lugar debemos concretar que desde nuestra perspectiva, historieta, cómics y tebeos son sinónimos y los utilizaremos indistintamente, aunque el término más apropiado para referirnos en Latinoamérica y sobre todo en Argentina sea el de Historietas. Todos ellos, junto a las viñetas en general, las distintas denominaciones según ámbitos geográficos como bande dessinée, fumetti o manga, el humor gráfico o el reciente formato de la novela gráfica, forman parte de una forma artística con entidad propia conocida como arte secuencial o noveno arte. Generalmente desde el ámbito académico se ha extendido el término narración gráfica que engloba a todo este tipo de obras.

En relación con la Literatura Infantil y Juvenil (LIJ) debemos aclarar que las historietas no están enfocadas exclusivamente a un público infantil y juvenil y muchas de las miradas peyorativas sobre el cómic caen en el error de considerar que son obras menores por este motivo. Ni la LIJ son obras menores, ni el cómic es exclusivo de la LIJ. El género del álbum ilustrado, que comparte con el cómic la narración en imágenes y palabras, sí que es propio de la LIJ porque el lector principal es el infantil, aunque el adulto también pueda disfrutar de sus ilustraciones. Sin embargo muchas de las historietas que veremos son aptas tanto para un público infantil o juvenil como para personas adultas que sabrán interpretar muchas de las cuestiones que nos plantean dichas historias.

\section{El Gaucho y su literatura}

Aunque la labor del vaquero en la pampa rioplatense se puede remontar hasta el siglo XVII, se considera que es a lo largo del siglo XIX cuando se desarrolla esta figura creando un icono de la cultura argentina. Bonifacio del Carril (1978) destaca como peculiaridades del gaucho argentino en primer lugar su naturaleza errante, y en segundo, su condición de alzado o fugado de la justicia. Son estas condiciones las que originaron, de cierta manera, lo que se conoce como «la leyenda del gaucho» y de toda la literatura que lo tuvo por protagonista. Dicha figura ha sido tratada desde distintas perspectivas, partiendo de un modelo negativo como puede ser el "gaucho malo» que se refleja en el Facundo (1845) de Domingo Faustino Sarmiento, culpable de los atrasos culturales de su país, hasta la reivindicación patriótica de José Hernández y su Martín Fierro (1872) como arquetipo de la nación argentina.

La sección americana de la Biblioteca Virtual Miguel de Cervantes tiene un completo portal dedicado a la literatura gauchesca dirigido por Pedro Luis Barcia http://www. cervantesvirtual.com/portales/literatura_gauchesca/ que nos puede servir de introducción a las múltiples vertientes de este género. Aunque la mayor parte de la crítica considera a la literatura gauchesca como un género poético veremos que llega a todas las artes, creando una iconografía propia (Carril, 1978) que como veremos, también tiene una importante tradición en la ilustración y la historieta. El citado portal digital ya nos habla en su introducción del cómic como un elemento más de esta literatura:

Desde las payadas de los troveros pampeanos, hasta el disparatado cómic gaucho de Fontanarrosa, sin
La figura del gaucho en la historieta argentina. De las versiones del Martín Fierro a Inodoro Pereyra JOSÉ ROVIRA-COLLADO 
dejar atrás a los poetas clásicos gauchescos y la novela de temática gaucha de principios del xx, la vida literaria de este personaje ha generado una de las producciones más originales de la literatura latinoamericana. (Barcia. BVMC).

Pero para conocer más de esta figura es imprescindible remontarnos a una de las primeras descripciones del gaucho, la que nos ofrece Hilario Ascasubi en su obra Santos Vega o Los Mellizos de la Flor (1850):

El gaucho es el habitante de los campos argentinos; es sumamente experto en el manejo del caballo y en todos los ejercicios del pastoreo. Por lo regular es pobre, pero libre e independiente a causa de su misma pobreza y de sus pocas necesidades; es hospitalario en su rancho, lleno de inteligencia y de astucia, ágil de cuerpo, corto de palabras, enérgico y prudente en sus acciones, muy cauto para comunicarse con los extraños, de un tinte poético y supersticioso en sus creencias y lenguaje, y extraordinariamente diestro para viajar solo por los inmensos desiertos del país, procurándose alimentos, caballos, y demás con sólo su lazo y las bolas (Ascasubi. Versión digital BVMC).

Jorge B. Ribera (1968) hace un completo recorrido sobre los orígenes poéticos del género gauchesco que sirven como precedentes de las obras que luego se considerarán como canónicas. Sin lugar a dudas, es José Hernández el máximo exponente de la literatura gauchesca y padre de la literatura argentina. Como otros autores gauchescos comienza sus escritos en diversos periódicos En 1872 publica la obra que iba a consagrar el género: El gaucho Martín Fierro que obtuvo un éxito inmediato, sucediéndose once reimpresiones en menos de seis años, "a parte del indudable valor literario, la importancia de esta obra reside en haber convertido a un personaje marginal de la sociedad argentina del momento, en poco menos, como se ha sugerido, que el representante principal de un pretendido «canon argentino». No son pocas las voces que han apelado al carácter heroico del poema para explicar este fenómeno desde una posición nacionalista.» (Barcia. BVMC)

Podemos identificar como nudos temáticos la libertad y la justicia el tono de queja y el lenguaje popular, convirtiendo a su personaje en mito. En 1879, Hernández publica La vuelta de Martín Fierro. En el mismo prólogo repite algunos de los valores que considera principales a cerca de su obra: la universalidad del personaje y el carácter popular del poema:

El gaucho no aprende a cantar. Su único maestro es la espléndida naturaleza que en variados y majestuosos panoramas se extiende delante de sus ojos. Canta porque hay en él cierto impulso moral, algo de métrico, de rítmico que domina en su organización, y que lo lleva hasta el extraordinario extremo de que todos sus refranes, sus dichos agudos, sus proverbios comunes son expresados en dos versos octosílabos perfectamente medidos, acentuados con inflexible regularidad, llenos de armonía, de sentimiento y de profunda intención. Eso mismo hace muy difícil, si no de todo punto imposible, distinguir y separar cuáles son los pensamientos originales del autor y cuáles los que son recogidos de las fuentes populares (Hernández).

\section{Historietas de Gauchos}

Manuel Barrero, director de Tebeosfera, portal fundamental para la reflexión teórica en torno al cómic, en una entrevista a Carlos Trillo, uno de los principales historietistas argentinos y autor junto con Guillermo Saccomano de una Historia de la bistorieta argentina (1980) nos hace una perfecta introducción a la creación del género gauchesco en viñetas:

Volviendo al pasado, a lo gauchesco (lo criollista, la mitología genuinamente argentina)... lo desarrollaron sobre todo: Raúl Roux (con «El tigre de los llanos», en 1929), Enrique Rapela («Cirilo», 1939), Walter Ciocca («Fuerte Argentino», 1953), Casalla y Cao ("Cabo Savino», 1951), y luego Oesterheld, Arancio, Roume y otros pocos hasta llegar a la mitología gauchesca que dibujó Breccia para SuperHUM(R)... ¿Se ha echado en falta más historietistas argentinos 
comprometidos con este apartado de la identidad nacional? (Barrero, Tebeosfera).

Aunque no cita a Lindor Covas, que es posiblemente el principal modelo junto con los dos personajes centrales tratados, Manuel Barrero nos introduce en la creación de un género propio dentro de una tradición fundamental dentro la narración gráfica, como son las historietas argentinas. En la citada entrevista, Trillo reconoce la relevancia de dicho género: «Lo gauchesco constituyó siempre un subgénero, una especie de western argentino que, durante décadas tuvo una enorme repercusión.» Dichas viñetas se repartían por las páginas de distintas revistas y en ellas se reflejaban todos los aspectos de la tradición gauchesca, la relación con la pampa y la disputa entre civilización y barbarie:

El muy popular diario vespertino La Razón debía un buen número de sus muchos lectores a las aventuras de «Lindor Covas, el cimarrón», que llevó adelante durante décadas Walter Ciocca. Ciocca, como Rapela, el dibujante de «El Huinca», que paseó por otros diarios y varias revistas, eran profundos conocedores del hombre de campo, sabían cómo gauchos e indios ponían los aperos y los estribos a sus caballos, entendían de animales, sabían dibujar el caballo criollo con su particular alzada. Además, las historias que creaban eran muy humanas, aventuras del tipo del film americano Soldier Blue se vivían en las páginas de las revistas de historietas décadas antes de ese revisionismo norteamericano sobre el papel de los indios en la historia, etc. (Trillo, Entrevista en Tebeosfera)

Sin embargo, antes de entrar en el recorrido por las principales historietas de gauchos, no debemos olvidar la figura de Patoruzú creado en 1928 por Dante Quinterno como personaje secundario de unas tiras de la revista Crítica. Tal fue el éxito que pronto tuvo una colección propia y en 1936 apareció una revista con su propio nombre, convirtiéndose en un clásico de la historieta. El cacique Patoruzú «el último de los indios tehuelches» significa también una representación del criollismo desde la perspectiva del humor gráfico, fundamental también en el mundo del cómic, como veremos en el último gaucho analizado. Aunque es un indio, muchos de sus características son propias de los gauchos: «En las peleas de Patoruzú siempre aparecen en algún momento las boleadoras, y lo que inmediatamente se sugiere es que lo que da fuerza al indio son virtudes gauchas, virtudes de la tierra. Pero virtudes gauchas, no indias» (Masotta, 166).

Jorge Sala (2010) hace un análisis del proceso de legitimación del gaucho en las historietas y el humor gráfico, a través de la obra de Florencio Molina Campos, ilustrador de gauchos para varios formatos entre 1926 y 1931; Tulio Lovato, ilustrador en las primeras etapas de Patoruzú y Juan Oliva, autor de Rancagua y Rendija, considerado como el gaucho en la ciudad. Muchas de estas adaptaciones pueden considerarse una transgresión del arquetipo del personaje, como también lo son otras obras de la tradición (Souto, 620).

Estamos hablando de una larga tradición que se reparte principalmente por múltiples revistas a lo largo de muchos años por lo que una descripción pormenorizada es imposible en estas páginas. A continuación comentaremos los que consideramos los principales hitos.

Seguramente el gaucho más importante de la historieta argentina, sin contar a Inodoro Pereyra, del que luego hablaremos, sea Lindor Covas, de Walter Ciocca, aparecido en 1954. Anteriormente Ciocca ya había adaptado historias de amplia difusión para la revista $L a$ Razón, como Una excursión a los indios ranqueles, Juan Cuello, Hormiga negra o Santos Vega (1948), las historias del mítico gaucho recogidas por Bartolomé Mitre (1854) e Hilario Ascasubi Santos Vega o los mellizos de la flor (París 1872), entre otros.

También en 1953 publicó Hilario Leiva, su primera obra con argumento propio. La mayoría de estas historias duraban siete u ocho meses y al finalizarlas, Ciocca se alternaba con otros artistas como Casalla para ir proponiendo novedades al público. Lindor Covas protagonizó por décadas una de las más famosas y perdurables tiras de temática gauchesca, tanto por su dinámico tratamiento como por la personalidad del personaje. Entrevistado por Sasturain en 1978, Walter Ciocca explica:

Lo fui sacando de la realidad, de las lecturas de Benito Lynch, de Guillermo Hudson, de Sarmiento. He tenido que tejer infinidad de temas y argumentos, evitando siempre la violencia, la parte más negra de la vida de los gauchos con sus puñaladas que van y vienen. Posiblemente yo en algo falté a la verdad, pero Lindor no se parece a los gauchos malos de Gutiérrez
La figura del gaucho en la historieta argentina. De las versiones del Martín Fierro a Inodoro Pereyra JOSÉ ROVIRA-COLLADO 
ni tampoco al gaucho bravo de Hernández. Lindor es, guardando las distancias, un Quijote, un hombre bueno como los hay en la realidad (Ciocca, en Trillo y Saccomano, Cap. 12).

Lindor Covas aparece en el Buenos Aires de Rosas, entre 1845 y 1865 más o menos, como un joven porteño de clase media, con un hermano oficial del ejército federal. En la primera etapa, admira a los unitarios hasta que lo invitan a viajar a Montevideo para unirse al bloqueo del Río de la Plata. Desde ese momento se siente traicionado y escapa y se muestra rebelde ante cualquier autoridad. En su huida va teniendo aventuras por la frontera hasta convertirse en un auténtico gaucho cimarrón. Ciocca toma conciencia de la tragedia del gaucho y su protagonista va padeciendo distintos problemas. Atribuye su desaparición a dos hechos fundamentales: esos hombres indómitos eran considerados como parias por las autoridades que los perseguían implacablemente y el progreso, representado por las alambradas, termina por destruir la libertad de la llanura. Entre estos problemas, persiste la visión de Ciocca del espíritu gauchesco, lleno de hidalguía , que reúne bondad y desinterés en apoyar al prójimo junto con una ferocidad en la defensa de su libertad y aceptación de su destino. Tal fue el éxito que en 1963 se estrenó la película Lindor Covas, el cimarrón de dirigida por Carlos Cores.

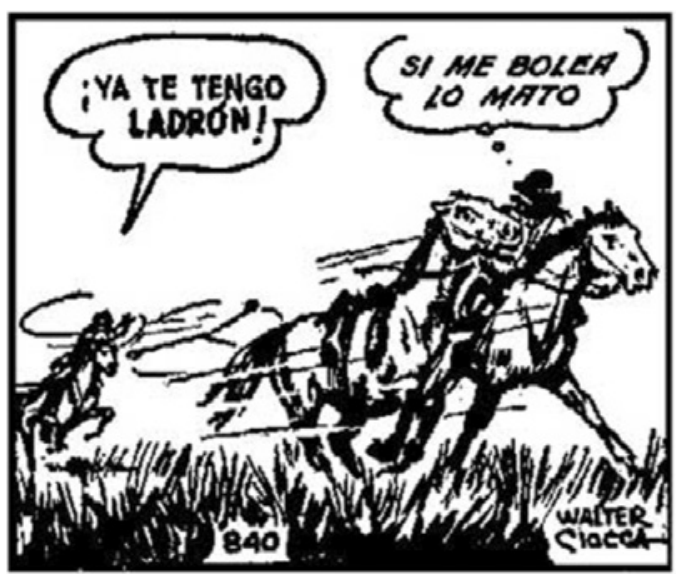

Lindor Covas, Ciocca 1954.

El otro gran personaje de esta historieta gauchesca inicial es el Cabo Savino de Carlos Chingolo Casalla, autor del que también hablaremos más adelante. Esta tira diaria nació en la revista La Razón en 1951 y es la historieta más longeva de la tradición argentina. El mismo Casalla (en Trillo y Saccomana Cap. 12), nos indica su recorrido. «la hice yo - dibujo y argumentodurante cinco meses, después volvió Ciocca; entonces me fui a El Gorrión y ahí siguió. Al final recaló en Columba y hasta ahora tuvo varios guionistas». Savino no es un gaucho, es un militar, pero es un antihéroe que recoge muchos elementos de esa tradición. El aprovecha sus conocimientos militares para describir una etapa más accesible a otros públicos:

Los problemas de la gauchesca están en la falta de visión de los editores, que creen que no se vende aquí y en la visión de los editores que saben que no se vende afuera. A mí me conviene hacer una serie del Oeste norteamericano y no una del Oeste argentino porque la otra se revende a todo el mundo y la gauchesca no. Y no es que el mundo de la gauchesca sea pobre, la culpa es nuestra si no lo sabemos dar a conocer. El Cabo Savino, por ejemplo, no es una figura extraña para los europeos (Casalla, en Trillo y Saccomana Cap. 12).

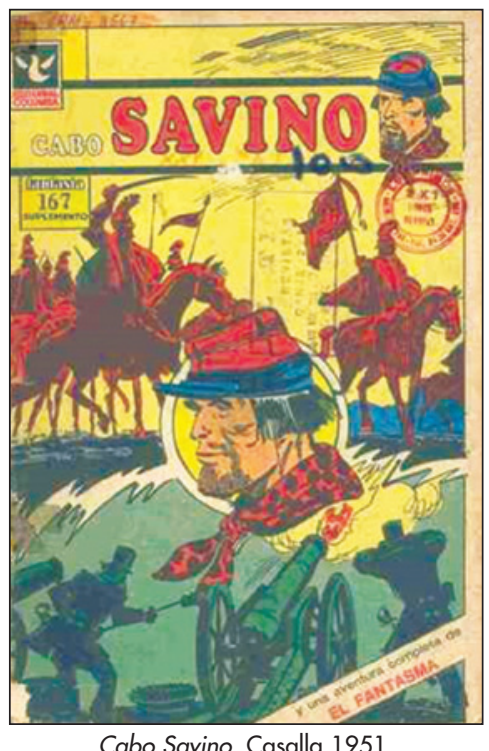

Oscar De Majo, en el especial de Tebeosfera sobre la historieta argentina (2008) comenta:

Nacido a principios de la década del ' 50 en las tiras del diario La Razón, también en 1957 recala en las ya tradicionales revistas de Columba El Cabo Savino, primero en El Tony, después en D'Artagnan y finalmente en Fantasía. El Cabo Savino es el primer militar de la historieta argentina y su autor, Carlos Cassalla, recrea con el personaje el mundo desesperante y marginado del soldado del fortín en las campañas al desierto (tipo Martín Fierro), reflejando a la perfección la ambientación histórica, las armas, el paisaje, la ropa. Uno de los grandes temas que cues- 
tiona Cassalla con esta historieta es la legalidad o no de estas campañas al desierto (De Majo).

La siguiente serie, Patria Vieja, apareció en 1958 en la revista Hora Cero Semanal de la mano de Carlos Roume y con guion de H.G. Oesterheld. Son historietas unitarias de ambiente argentino suponen una modernización de la tradición gauchesca. Supone una nueva visión del género de la mano de uno de los más grandes guionistas de la historia del cómic. En 1960 Juan Arancio tomo los lápices continuando con solvencia la labor de Rome. Oesterheld en una entrevista para la revista Dibujantes, comenta:

Patria Vieja nació del deseo largamente acariciado, y que nunca había podido realizar, de hacer una gran historia de nuestro pasado; siempre creí que lo nuestro puede ser, por lo menos, tan aventuroso como lo exótico. Aquí también el dibujante, Roume, sabe agregar lo suyo; pone alma en el dibujo y la historieta cobra toda una humanidad que desde ya obliga y espolea al autor. (Oesterheld, en Trillo y Saccomano Cap. 17).

El dibujante, Roume, entrevistado de Sasturaín, también reflexiona sobre las figuras centrales de la historieta:

Esos fueron los primeros indios, pampas y gauchos - poco más o menos- que dibujé, pero es que ya los tenía dentro (...) Ahora sé de esos hombres que son auténticos iniciados que no saben lo que son, que poseen toda esa sabiduría, esa belleza que los convierte en nuestra aristocracia. La verdadera, la del alma. La otra es solo su imagen (Roume, en Trillo y Saccomano Cap. 12).

Otro hito de las viñetas de temática gauchesca fue Enrique Rapela. Ya en 1939 crea su primer gaucho, Cirilo el audaz, que tuvo el mérito de ser la historieta pionera en mostrar los azares del hombre de la pampa. Esta es la primera respuesta identitaria de la historieta argentina antes la invasión de los temas extranjeros, fundamentalmente norteamericanos. El personaje es una afirmación de una identidad a través del propio folklore. El propio autor se jactaba de conocer perfectamente todo el paisaje autóctono que ilustró en obras como El jinete de fuego en la revista Intervalo (1948). Pero además de pionero, en 1969, coincidiendo con una revalo- rización del «pensamiento nacional» y una corriente de revisionismo histórico, Rapela es el responsable de El Huinca, una serie de historietas criollas para la editorial Cielosur. En esta se pretende crear una epopeya nacional con la imagen idealizada del gaucho, comparando la Conquista del desierto argentino con la del oeste norteamericano.

Estas son el núcleo fundamental de las creaciones clásicas del gaucho en historietas. Sin embargo, a la hora de buscar referencias sobre el gaucho en viñetas también podemos acceder a otras aproximaciones al personaje o al concepto, en este caso, ajenas a la historieta y a la historia argentina.

Coetáneo a la tradición inicial,

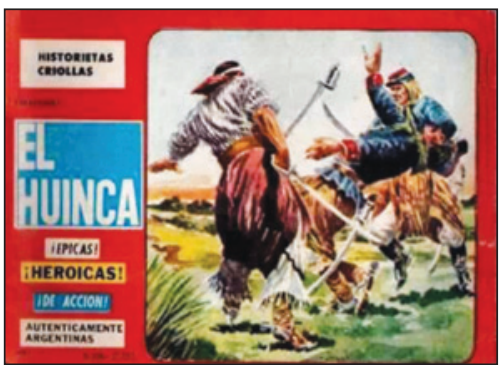

El Huinca Rapela 1969. pero con una concepción totalmente distinta, encontramos la propuesta norteamericana del Red Gaucho un superhéroe de los años cuarenta. Publicado por Fawcett Publications apareció por primera vez en Nickel Comics, \#4 en junio de 1940, de guionista desconocido pero con ilustraciones de Harry Anderson. Responde a la moda del cómic norteamericano de buscar personajes y paisajes exóticos, pero siempre desde una perspectiva metropolitana y en ocasiones racista «that Red was born in South America of Yankee parents». Sobre el modelo tradicional del Zorro o del Hombre Enmascarado se nos vuelve a presentar un típico héroe que recoge pocas de las tradiciones gauchescas: «The Red Gaucho had the outward form of a superhero, with a distinctive look (red pants and matching cape) and a catchy name, but lacked the secret identity that would also place him in that genre (which also made him dissimilar to Zorro, with whom he's sometimes compared)» (Markenstein).

Años después, en el número 215 de la mítica Detective Comics aparece El Gaucho, o "The Gaucho of Argentina», en la historia «The Batmen of All Nations», publicada en enero de 1955. Escrita por Edmond Hamilton con dibujos de Shelly Moldoff y tintas de Charles Paris, es una obra típica de la época dorada de los superhéroes de DC. En 1957 en «World's Finest Comics» vuelve a aparecer el personaje, pero después perdemos la pista

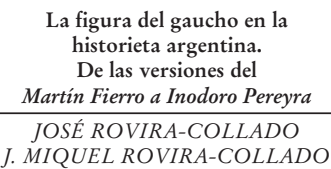

La figura del gaucho en la De las versiones del JOSÉ ROVIRA-COLLADO J. MIQUEL ROVIRA-COLLADO 


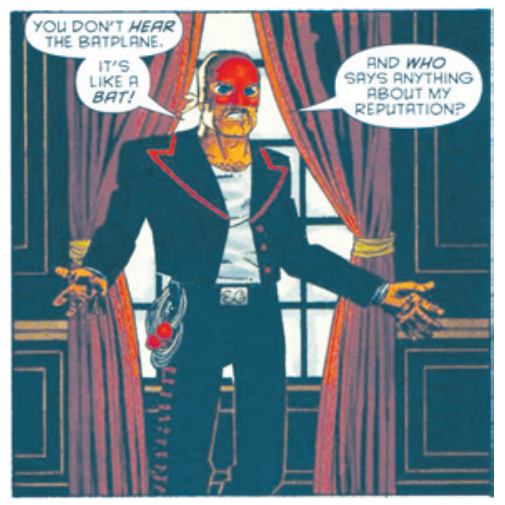

Batman Inc 2007 hasta Infinity Inc \#34, (enero 1987), en donde se integra en los «Guardianes Globales», un supergrupo internacional según el modelo de la Sociedad y la Liga de la Justicia.

El Gaucho se alimenta directamente del estereotipo nacional del gaucho, tal como es imaginado por un escritor de ciencia ficción de Ohio que trabajó bastante escribiendo comics. No sorprende por la época, pero viéndolo hoy resulta gracioso como veía un yanqui a un gaucho típico, todo vestido de verde y con una capa amarilla, y con unas boleadoras bastante particulares, su «bolo» (Mollo).

Este personaje fue rescatado por Grant Morrison en 2007, para los números de $\mathrm{Ba}$ -

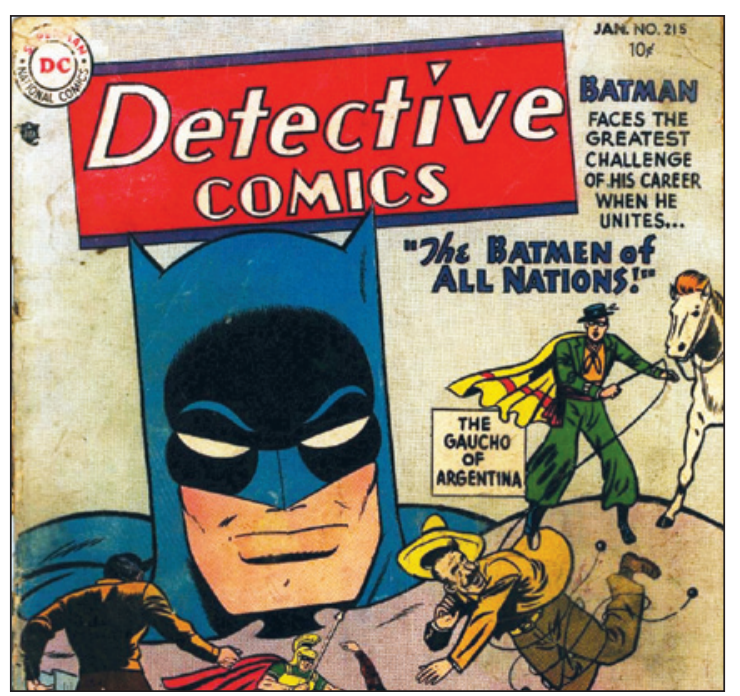

Detective Comics 215, 1955. tman Incorporated \#3, 4, 5 y 6 ilustrado por Yanick Paquette $y$ entintado por Michel Lacombe, Morrison reinventa un poco al Gaucho y su apariencia, con una máscara roja, chaqueta de cuero y una moto en lugar del caballo. El personaje adquiere protagonismo en estos números como compañero de Batman y aunque repite estereotipos, demuestra una mayor investigación sobre la Argentina de la época, la del siglo XXI, no la del XIX y XX. En la historia Batman y el Gaucho salvan al Cimarrón, un miembro del supergrupo argentino SuperMalón. Este grupo hizo su primera aparición en el anual \#13 de Flash, titulado Haunted Pampas, (2000) escrito por Chuck Dixon y dibujado por el argentino Quique Alcatena. Es posible que este ilustrador no tenga un gran recuerdo de este encargo, porque todos los integrantes (Cimarrón, Pampero, Vizacacha, Cachiru, y Lobizón, entre otros), representan distintos tópicos argentinos adaptados a distintos superpoderes desde una perspectiva muy estadounidense.

En estas visiones internacionales, encona figura del gaucho en la historieta argentina.
De las versiones del Martín Fierro a Inodoro Pereyra JOSÉ ROVIRA-COLLADO J. MIQUEL ROVIRA-COLLADO tramos también, bajo el título de El Gaucho (1991), una obra ilustrada por Milo Manara, con guión de Hugo Pratt que ya habían cola- borado anteriormente en Un'estate indiana, (1983). A pesar de la rotundidad del título, apenas tiene que ver con lo gauchesco. Urrero (2009) hace un breve recorrido por esta historia sobre Tom Browne, es un anciano casi centenario que habita en la toldería del cacique Namuncurá. Allí narra los acontecimientos que se remontan a 1806 , cuando un jovencísimo Browne, tambor de infantería, viaja rumbo a Buenos Aires junto la escuadra inglesa al mando de Sir Home Popham. La historia se aleja de la representación tradicional del gaucho y se centra más en las historias de los personajes y las ilustraciones eróticas de Manara. Quizá el proyecto original pretendía desarrollar la vertiente gauchesca del protagonista, pero en esta obra el italoargentino Hugo Pratt se quedó solamente en el título.

Con estas desviaciones de los modelos clásicos de guachos, muchos podrían pensar que la visión gauchesca tradicional está agotada para las viñetas y que ya no hay interés por las adaptaciones o creaciones concretas de esta temática. Sin embargo, a través del Archivo de Tebeos y Autores Españoles e Hispanoamericanos y su página de Facebook [https://www.facebook.com/ groups/626933777326750/] y con la colaboración del crítico Rafael Marín, hemos entrado en contacto con distintos autores que han seguido editando historias de gauchos. Muchas son creaciones anteriores, pero que gracias a las posibilidades de Internet han resucitado el interés de los lectores y nos encontramos con nuevas reediciones.

Un lugar destacado de estas nuevas producciones de género gauchesco lo ocupa Pampa una serie de tres novelas gráficas con guion de Jorge Zetner y dibujo de Carlos Nine. Luna de sangre (2003), Luna de plata (2004) y Luna de agua (2005). Es destacable porque además se publicó en Francia (Dargaud) y en España (Sins entido). Nine también ha publicado Prints of the west una sátira del oeste americana. La trama de Pam$p a$ transcurre a través de un facón, el típico cuchillo gaucho que pasa de mano en mano a través de diferentes personajes y circunstancia recuperando precisamente un tópico habitual en los seriales del oeste.

De los distintos contactos, el primero fue con el uruguayo William Gezzio. A través de su blog [http://mundodibujado.blogspot. 
com.es/] podemos tener información sobre mucha de su producción artística. Además pudimos realizarle una entrevista respecto al tema:

Hay un sitio en Facebook: La bistorieta gauchesca, [https://www.facebook.com/La-historieta-gauchesca-304720722920886/info/?tab=page_info] donde pueden ver mucho material sobre el tema. De Santos hicimos un libro donde se recopilaron unas 120 páginas, fue por los 80s del pasado siglo y está agotado. El año pasado dibujé 65 páginas sobre un guion de Rodolfo Santullo que está en Marche un cuadrito. (...) El libro de Santos Cruz, una pequeña edición que hizo la editorial ARCA de Montevideo constaba de 110 págs, más tapas y compilaba las 9 primeras historias del gaucho, ubicadas entre 1811 y 1820, mostrando diversas vivencias del gaucho oriental, desde su ambiente familiar hasta la participación forzada en las batallas campales contra los invasores. Otro destacado dibujante uruguayo: José Rivera, ya retirado de todo quehacer artístico, publicó en forma de tiras diarias, la adaptación de la obra de Eduardo Acevedo: Ismael, (1961-63) que fue muy elogiada y sigue siendo uno de nuestros íconos en lo que a gauchos se refiere. Gracias por preocuparse por el gaucho (William Gezzio, Entrevista personal septiembre 2015)

Su obra fundamental es Santos Cruz, una historia de unas 102 páginas que comenzó en 1971 en la revista Charoná, editada por Sergio Boffano y Juan J. Ravaioli. Como él mismo nos relata (Gezzio Santos Cruz), el personaje cambió de nombre, posiblemente para relacionarlo con el ya citado Santos Vega. Podemos pensar que este autor es del grupo clásico, pero a través de la web social podemos acceder a gran parte de su obra descatalogada y sigue trabajando en proyectos como El último gaucho (2012) sobre un texto de Alberto Vacarezza.

A través de Gezzio accedimos al portal La Historieta Patagónica [http://historietapatagonica.blogspot.com.ar/] un completo espacio dedicado completamente al tema que nos ocupa. También la editorial La Duendes tiene un blog [http://laduendes.blogspot.com. es/] donde comenta y promociona sus proyectos, muchos relacionados con la tradición gauchesca.

En estos momentos y a través de estos espacios podemos destacar principalmente la obra de José Massaroli. También es un autor de la década de los ochenta, pero que últimamente ha recuperado su obra. En su blog [http://jose-massaroli.blogspot.com. $\mathrm{ar} /$ ] podemos encontrar referencias y muchas ilustraciones de la adaptación de Facundo o la obra El Chacho. Pero si debemos citar alguna obra es la edición de Juan Moreira, legendario personaje gauchesco inmortalizado por Eduardo Gutiérrez (La Patria Argentina 1879-80), que fue dibujado por Massaroli (Dario La Voz, octubre 1983 y febrero 1984). Ante el interés suscitado por su publicación en Internet a través de los anteriores blog, La Duendes lo publicó en formato de novela gráfica en 2010. En el prólogo del editor Alejandro Aguado leemos (Massaroli, Juan Moreria):

Desde que se extinguió la legendaria editorial Columba en el año 2001, tras setenta años de vida, el género del gauchesco dejó de tener presencia en la historieta argentina. Las primeras historietas publicadas, propiamente dichas del género del gauchesco, un género netamente argentino, aunque emparentado con el western, se remontan a la década del 30. El personaje inaugural fue "Cirilo, el audaz», de Rapela. El género nació del cruce del mito literario del gaucho, de la historia, de las costumbres y paisajes rurales, de un país en que el grueso de su población pertenecía al ámbito rural. Pero el país cambió, la distribución se modificó y en la actualidad la población se concentra en las urbes. Se sabe que en las grandes urbes la relación con

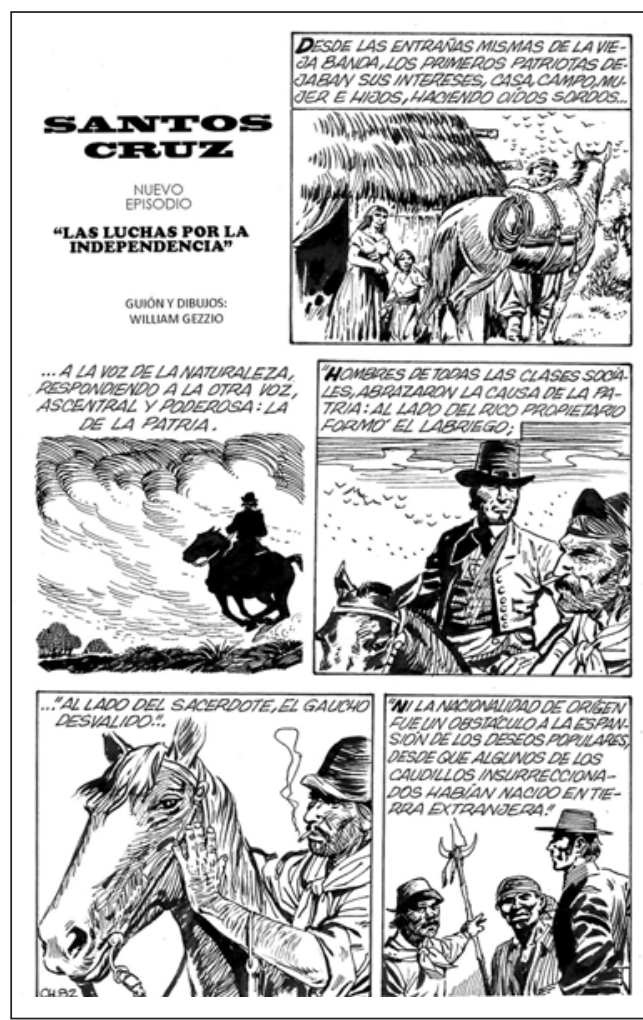

Santos Cruz, Gezzio 1971.

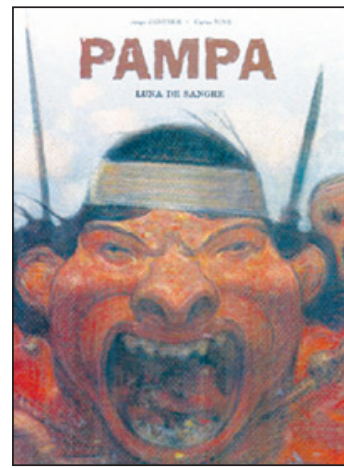

Portada Pampa Luna de Sangre Zetner y Nine 2003 la tierra se restringe a patios, plazas, paseos y canteros. El gaucho es hijo de la tierra, de campo abierto, nada más ajeno a la vida de la ciudad. En el caso de la historieta nacional, el campo y los gauchos pasaron al ámbito de los recuerdos, a conformar parte de su patrimonio histórico, de un género que durante décadas gozó de una enorme aceptación.

Nos encontramos ante un nuevo resurgir del género. O como se ha preferido llamar un Rebrote de la historieta argentina de aventuras, nombre con el que también se conoce a

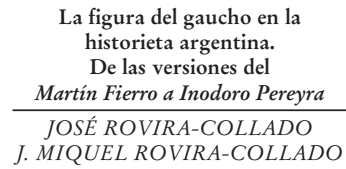




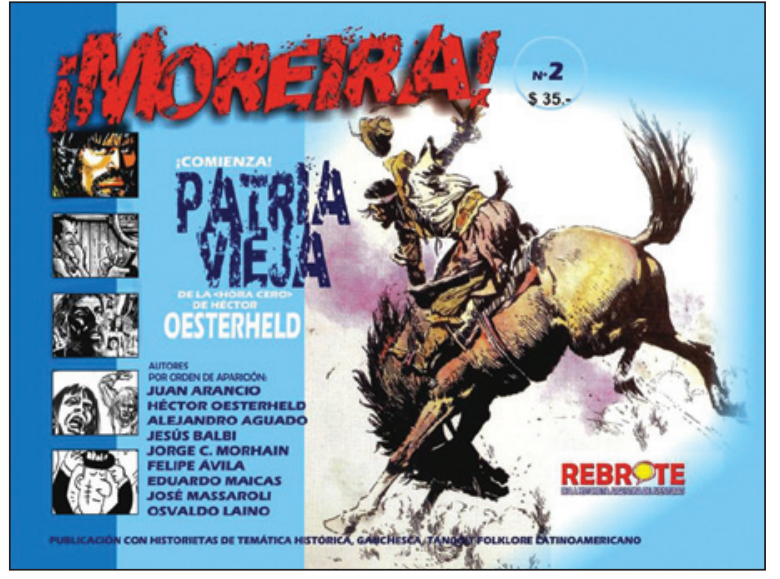

Portada Moreira-Rebrote \#2. Diciembre 2015. la Revista Moreira lanzada en 2015, que lleva como subtítulo «Publicación con historietas de temática gauchesca, tango y folklore latinoamericano» donde tiene una activa participación Massaroli. Si en el \#1 encontramos la portada de Juan Moreira, el \#2 hace referencia a la Patria Vieja con el importante reclamo de Oesterheld.

\section{El Martín Fierro ilustrado}

Como hemos visto, nos encontramos ante un renacimiento del género por el interés de los lectores. Sin embargo, un personaje que nunca ha caducado es el gaucho por excelencia, el Martín Fierro. Es tal la relevancia del personaje de José Hernández, pilar de la tradición gauchesca y de la identidad argentina, que, como no podía ser de otra manera, ocupa un espacio concreto de nuestra investigación porque es el que tiene más versiones gráficas. Recordemos además que una de las principales revistas de historietas lleva por nombre Fierro, en homenaje al héroe. Aunque en la actualidad es considerada una única obra con dos partes «La ida» $\mathrm{y}$ «La vuelta» fue editada como El Gaucho Martín Fierro (1872) y La vuelta de Martín Fierro (1879).

Juliana María Lozada (2012) recoge en una reciente investigación un catálogo de veinte versiones ilustradas del Martín Fierro, donde encontramos desde el texto literario acompañado por ilustraciones aisladas hasta adaptaciones en viñetas o cuadros, donde se conjuga el arte literario de José Hernández junto con el del ilustrador. La primera versión ilustrada fue la portada y diez ilustraciones que Carlos Clérice realizó en 1879 para la edición de La vuelta de Martín Fierro, en la Librería del Plata de Buenos Aires. Esta investigación también cita, por orden alfabético, las siguientes versiones ilustradas por: Carlos Alonso (1960), Juan Arancio (2010), Adolfo Bellocq (1930), Ricardo Carpani (1999), Juan Carlos Castagnino (1962), Carlos Clérice (1879), Tomás Di Taranto (1972), Roberto Fontanarrosa
(2004), Roberto González (1978), Alfredo Guido (1969), Alberto Güiraldes, en una traducción el inglés editada por Oxford Press (1935), Horacio Alfredo Isaurralde (1998), Juan Lamela (1963), Luis Macaya (1958), Eleodoro Marenco, (1949), Roberto Páez (1975), Tito Saubidet (1937), Luis Scafati (2004), Osvaldo Svanascini (1948), y Mario Zavattaro (1997).

Aunque es una recopilación exhaustiva, podemos citar otras propuestas como la publicada en 2011 por Ediciones Larivière sobre los trece primeros cantos de La ida, con ilustraciones de autoras y autores españoles que van desde el expresionismo hasta el cómic. La tapa es de Manuel Álvarez Junco y cada canto lleva dos ilustraciones de Jorge González, Fernando Vicente, Javier Olivares, Javier Zabala, Juan Berrio, Eva Vázquez, Pep Brocal, Elisabeth Nogales, Gonzalo Torné, Joaquín López Cruces, José Luis Ágreda, Miguel RuizPoveda y Ana Matías.

Además, la selección de Lozada se olvida de algunas adaptaciones fundamentales al cómic como son las de H. G. Oesterherld y Carlos Roume (1972), Alberto Breccia (1992) y Carlos Chingolo Casalla (2000). Estas, junto con las de Castagnino y Fontanarrosa, son en nuestra opinión las versiones más destacadas.

Aunque no sea un cómic, debemos partir de la edición ilustrada en 1962 por Juan Carlos Castagnino ya que se convirtió en icónica. Este pintor ya había recibido distintos reconocimientos a su trabajo y cuando en 1962 fue nombrado miembro de la Academia Nacional de las Bellas Artes, la de Editorial Universitaria de Buenos Aires le encargó esta edición que cuenta con diez láminas en formato grande y una litografía. Según Lozada (14) «Para la generación de argentinos que tuvieron entre manos las ediciones de Eudeba, el Martín Fierro de Castagnino era la cara del gaucho. Luego de los primeros folletos que gozaron de notable popularidad, esta fue la edición más difundida de la obra» con casi doscientos cincuenta mil ejemplares en las primeras seis ediciones. La interpretación de los cantos de la obra a través de tan pocas imágenes se convierten en icónicos y marcarán la interpretación de las ilustraciones posteriores.

Anteriores a esta edición encontramos otras versiones que se acercan al Martín Fierro como según informa Luis Rosales. Por ejemplo el peruano Paco Cisneros para la revista argentina Aventuras ya hizo una primera adaptación 


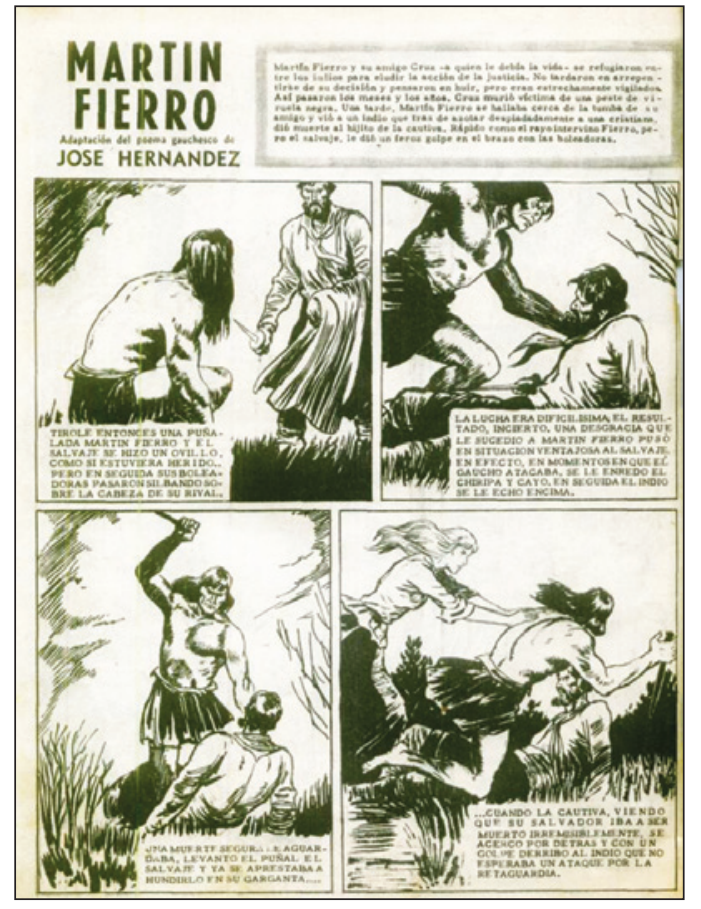

Martín Fierro, Cisneros 1947.

en 1947 que se ajusta más a los héroes de cómic norteamericano como Tarzán o Conan que a las figuras gauchescas.

Debemos destacar la adaptación en historieta de 1972 para la revista Billiken realizada por Carlos Roume y con guion de Héctor Germán Oesterheld. El texto propio del escritor de El Eternauta, se mezcla perfectamente con los versos de Hernández, por lo que la podemos considerar como la primera historieta del Martín Fierro. Además debemos destacar el trabajo del ilustrador, ya que tanto la vestimenta de los gauchos, así como las peleas con cuchillo, revelan no sólo talento artístico sino una esmerada documentación.

La siguiente adaptación también cuenta con los lápices de otro grande de la historieta argentina: Alberto Breccia. Ilustrador de los guiones de Oesterheld de Sherlock Time (1958), Mort Cinder (1962-1964) y la segunda versión del Eternauta, Breccia también nos propuso su visión del Fierro. En 1991, dos años antes de su muerte, se dedicó a preparar una edición para la editorial Lumen de la que disponemos de trece originales, bocetos y tres descartes. Por desgracia esa edición no vio la luz y no fue hasta 2004 cuando la editorial Doedytores obtiene de su viuda unas fotocopias en láser y decide publicarlas. Un trabajo póstumo pero que nos ofrece otra visión del gaucho, limitándose a ilustrar algunos episodios de La ida. Se aleja de las anteriores versiones en una serie de escenas que se acercan más a la visión de Molina Campos y Castagnino que a las típicas de cómic.
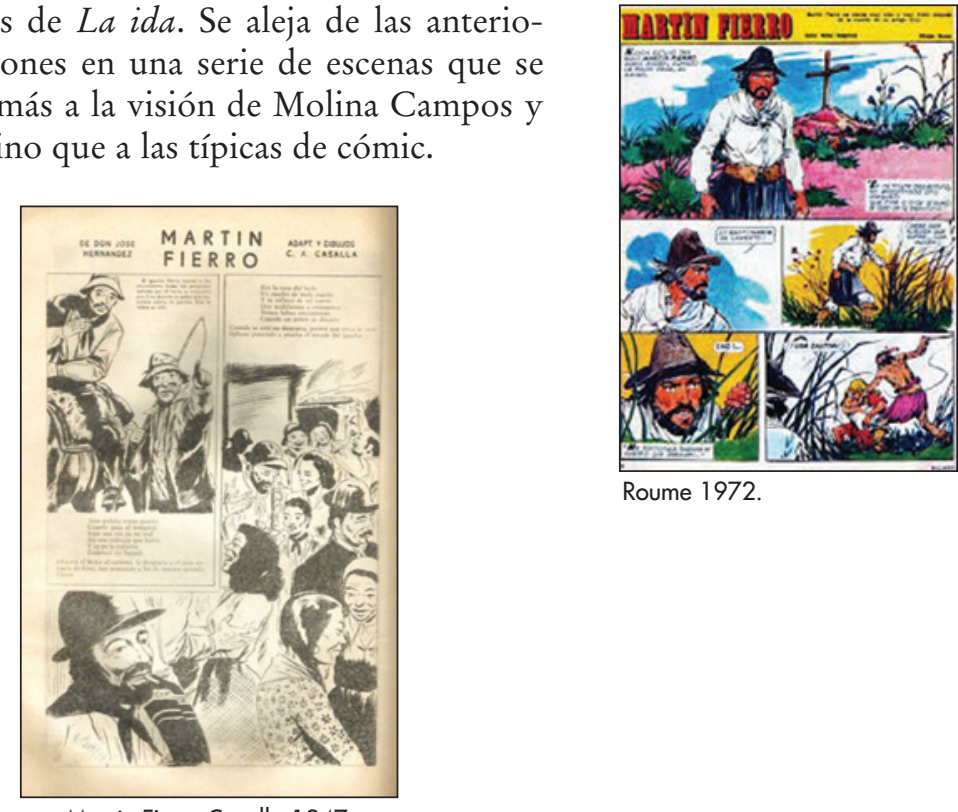

Roume 1972

Autor del Cabo Savino, el gacuho más longevo en la historieta argentina, Carlos Chingollo Casalla nos ofrece la que es posiblemente otra de las joyas de la ilustración gauchesca además de una intensa relación con el Fierro. Esta nace en una primera interpretación en su juventud, ya que realizó una versión cuando estaba realizando el servicio militar en 1947 para la revista El Soldado Argentino.

Pero es la edición del año 2000 , cuando ya era un autor totalmente reconocido, la que le valió los mayores reconocimientos. La segunda edición de 2003 además incluye veinticuatro dibujos explicativos sobre el vocabulario gauchesco, donde se muestra como un gran conocedor de sus usos y costumbres. En la propia edición comenta: «Editorial Coirón se complace en ofrecer esta segunda edición de Martín Fierro ilustrada por Chingolo Casalla, conocedor de usos y costumbres

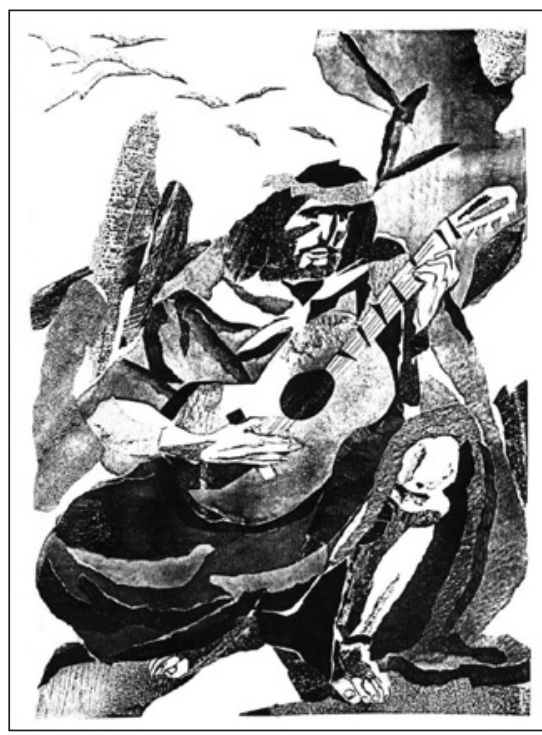

Martín Fierro Breccia 1991 gauchas, para que el lector la disfrute». En la web de la edición encontramos el siguiente comentario de Laura Calvo:

Basado en una prolija documentación de vestuario, ambientación y costumbres, elementos camperos y amas propias de aquella época, Casalla logra retratar con notable realismo al hombre de estas tierras, 


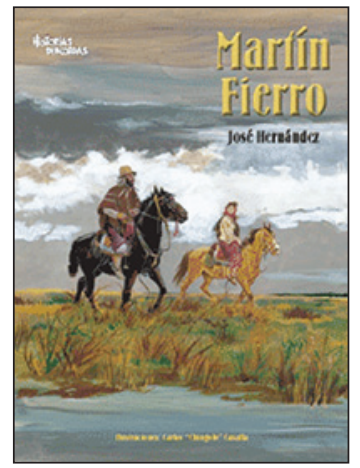

Portada M. Fierro Casalla 2003.

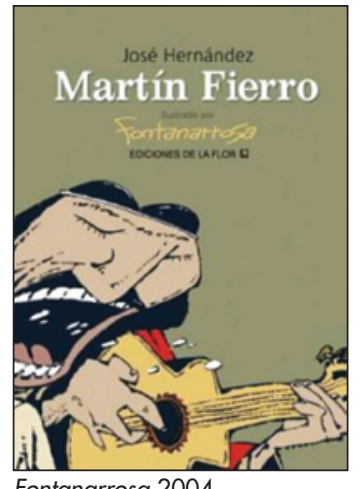

Fontanarrosa 2004 cunado poco valía la vida pero sí la intrepidez y el coraje. Con trazos fuertes nos muestra el sufrimiento, la soledad y las miserias del gaucho, el indio y el milico. El Cabo Savino, el Sargento Toro, el Capitán Camacho, son algunos de los personajes también presentes en su obra generosa y sostenida donde prevalece su estilo como una forma de representar nuestros arquetipos (Calvo).

Como última adaptación no debemos olvidar la realizada por Roberto Fontanarrosa de la que hablaremos en el siguiente punto. En este recorrido por las distintas obras, es fundamental mencionar los siguientes momentos o personajes que se repiten en todas las versiones. Por ejemplo, la guitarra se convierten en referente iconográfico de una tradición y con cada adaptación, cada generación ve dibujadas las imágenes e historias narradas por José Hernández, como la representación del indio, el viejo Vizcacha, la muerte de Cruz, o el propio Fierro con la guitarra:

Aquí me pongo a cantar

Al compás de la Vigüela,

Que el hombre lo desvela

Una pena extraordinaria

Como la ave solitaria

Con el cantar se consuela.

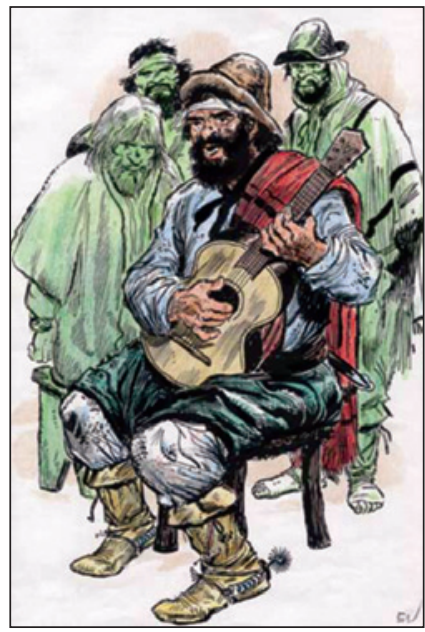

Guitarra Martín Fierro Casalla 2000.

...

Cantando me he de morir

Cantando me han de enterrar,

Y cantando he de llegar

Al pie del eterno padre:

Desde el vientre de mi madre

Vine a este mundo a cantar

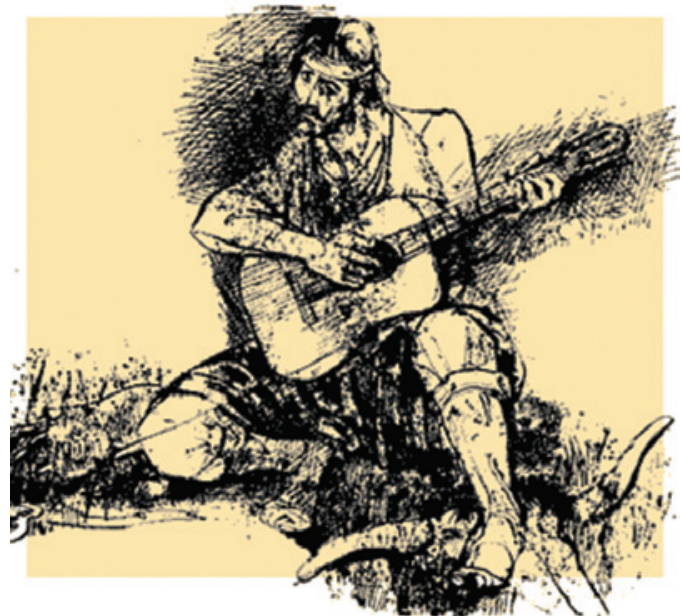

Guitarra Martín Fierro Castagnino 1962.

\section{Gauchadas del «negro» Roberto Fontana- rrosa}

Como casi todas las representaciones del gaucho, Inodoro Pereyra está inspirado en el Martín Fierro de José Hernández. Existe una clara relación de «El renegáu» Pereyra, uno de los principales personajes de Roberto Fontanarrosa con distintas adaptaciones del clásico. Homenaje o retrato irónico del gaucho, este personaje se convirtió en una de las visiones gauchescas más destacadas en el último cuarto del siglo XX, superando el límite de las historietas y convirtiéndose en un personaje icónico en Argentina y un referente del «argentinismo».

A lo largo de las historietas del personaje, se va desarrollando una personalidad muy marcada y unos personajes característicos donde la tradición gauchesca es tamizada por el humor propio de su autor. Pero debemos marcar la clara influencia de la obra de José Hernández en el personaje de Fontanarrosa. Ya en la primera historieta encontramos una clara alusión a un momento concreto del poema de Hernández. Cuando Inodoro está tranquilamente en una pulpería, unos soldados vienen a apresarle y él se defiende. Los versos originales del Martín Fierro:

\section{Tal vez en el corazón \\ le tocó un santo bendito \\ a un gaucho, que pegó el grito \\ y dijo: ¡Cruz no consiente \\ que se cometa el delito \\ de matar a un valiente!}

Se transforman en una viñeta cuando de repente, ante una situación similar, otro per- 
sonaje grita "Alto maulas, así no se mata a un valiente» y ambos se defienden de la agresión. Sin embargo, cuando el otro gaucho le anima a huir juntos, Inodoro responde: « $\dot{\text { Sabe }}$ lo que pasa? Que a esto ya me parece que lo leí en otra parte y yo quiero ser original...», declarando su independencia del texto hernadiano y una visión mucho más cínica y humorística. El propio Pereyra introduce en ocasiones una posible relación de parentesco con el Martín Fierro «mi viejo dijo que se había echado algún Fierro por ahí». Además, en la semblanza inicial del personaje podemos encontrar claras influencias de la versión ilustrada por Castagnino en 1962. Juan Sasturain (Inodoro Pereyra, 8) destaca esta relación:

Como se ve en la primera secuencia que reproduce esta amplia antología, el gaucho sanitario nace no sólo como sintética parodia argumental de un episodio ejemplar del Martín Fierro sino que en el arranque el dibujante trabajó a conciencia sobre la modalidad del trazo de Juan Carlos Castagnino, ilustrador de la edición más popular del clásico.

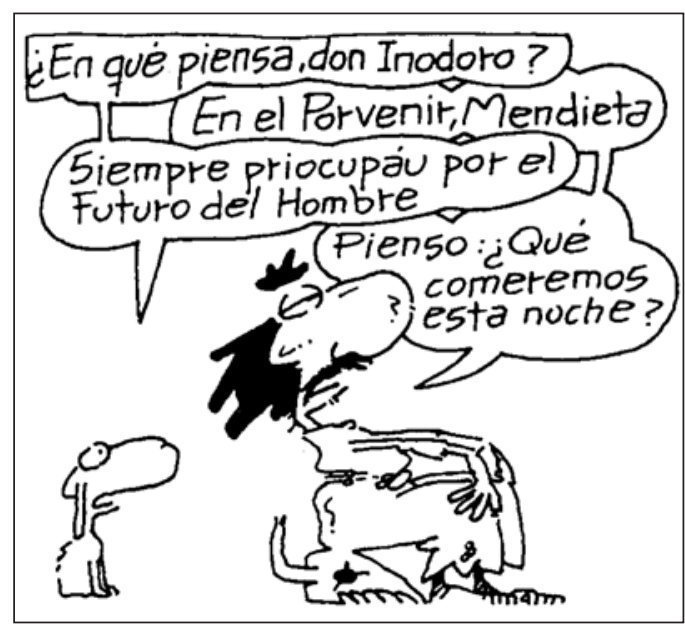

Inodoro Pereyra y Mendieta.

La primera aparición de Inodoro Pereyra es de finales de 1972, en la revista cordobesa Hortensia. Durante varios años estas historietas fueron un reclamo en dicha publicación, y este gaucho solitario de las pampas, que puede interpretarse como parodia del estereotipo, va recibiendo la visita de diversos y extraños personajes. Entre ellos destaca Mendieta, su inseparable perro, ya que en sus cuadritos «un caballo no cabía» y que en más de una ocasión, comparte los razonamientos de su amo a través de nubes de pensamiento en complicidad con el lector, reforzando el contrapunto cómico. Otro personaje fundamental será su pareja, Eulogia Tapia, inspirada en la zamba de Manuel J. Castilla con música del Cuchi Leguizamón «La Pomeña», que va evolucionado en aspecto y carácter a lo largo de la historia. Posteriormente el personaje pasa a las revistas Mengano y Siete Días, con aventuras por entregas, donde Mendieta se convierte en aliado y coprotagonista indispensable. En esta etapa aumenta la aventura con episodios de largo desarrollo y falso suspense, con Pereyra siempre en busca de nuevas aventuras.

En 1976 comienza su etapa de más éxito al llegar a la tira del Clarín, donde se vuelve a la historia unitaria, con un protagonista más relajado y alejado de la aventura, pero con mayor crítica y humor en sus diálogos en cada viñeta. El personaje pasó por diversas secciones del periódico, hasta que finalmente la tira fue incluida en el dominical Viva. Su labor ya no es la del aventurero ni homenaje paródico, se convierte en un crítico de la sociedad actual:

Fontanarrosa ha reflotado el mecanismo de los encuentros pero a partir de un Inodoro quieto, situado, que recibe visi-

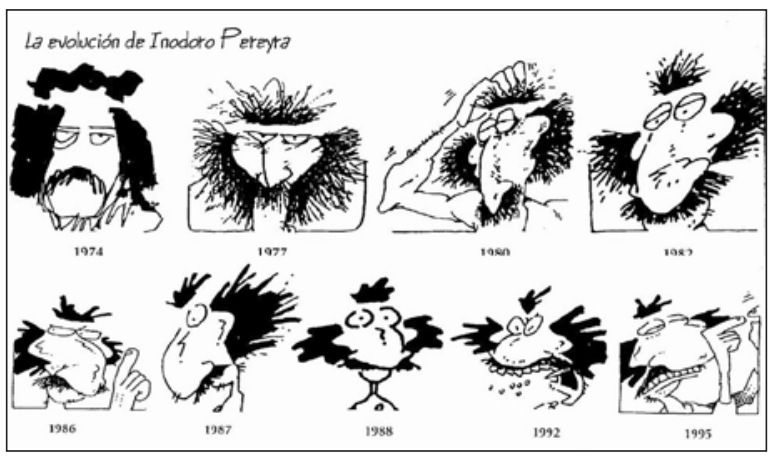

Evolución Pereyra.

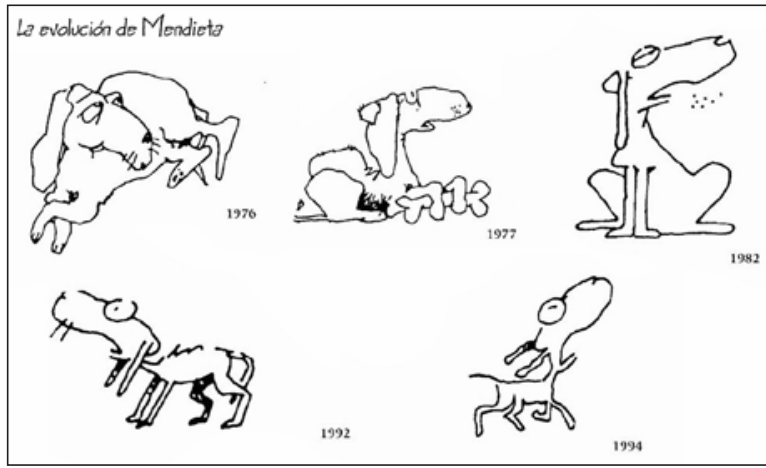

Evolución Mendieta. tas, ofertas, alguna provocación que soslaya. No le viene a buscar la aventura sino la cotidianeidad o la noticia. (...) Cuando el tema no viene de afuera, surge de la cotidianeidad del rancho, de avatares diarios; inclusive del calendario: el frío, las vacaciones de invierno, la fiesta de la primavera, el veraneo; para referirse, finalmente, al tema que domina muchas veces el momento desde la preocupación periodística: ecología, vinchuca, turismo al exterior, los alquileres y desalojos, compactadoras, la publicidad en la indumentaria, los avisos de los famosos, esa información que el lector maneja (Sasturain Domicilio de la aventura).

Fontanarrosa deja de referirse a historias de gauchos para utilizar a su «renegáu» como

\footnotetext{
La figura del gaucho en la historieta argentina. De las versiones del Martín Fierro a Inodoro Pereyra

JOSÉ ROVIRA-COLLADO J. MIQUEL ROVIRA-COLLADO
} 
un espectador privilegiado de la situación argentina que se atreve a decir y criticar lo que otros no se atreven. Las referencias a la actualidad son constantes e imprescindible para interpretar las historietas y sobre todo para reconocer la relevancia de este nuevo gaucho en viñetas:

En este sentido, nuestro punto aquí es que Inodoro Pereyra no escapa a esta manía de las citas y la intertextualidad, pero realiza esta operación en forma tan evidente que se constituye en metalenguaje. Es decir, que hace uso de este rasgo de estilo, pero llamando la atención sobre él de tal forma que lo parodia. En cierto punto se podría hablar de una parodia del pastiche. En concreto: el anacronismo desenfadado de Inodoro Pereyra no es mero formalismo posmoderno, sino una especie de descripción de que efectivamente vivimos en una sociedad "historizada», ahistórica* (Alén, 2010, p. 5)

Otras de las claras influencias en el personaje fue el Lindor Covas de Ciocca. En un reportaje a Inodoro Pereyra, le preguntaron "¿de qué personaje se siente amigo?» y el Renegáu responde: «Güeno, a veces viene a matear conmigo el Lindor Covas, claro, le gusta el mate cimarrón, lógicamente.»

Posiblemente fue la relevancia de Inodoro Pereyra como una revisión cómica de la tradición gauchesca que produce una gran revitalización de esta, la hizo que Fontanarrosa se encargara de la ya mencionada adaptación del Martín Fierro en 2004 para Ediciones De la Flor. Sasturaín destaca este hecho:

Es decir: más de treinta años después, Fontanarrosa accede a ilustrar el texto hernandiano desde la equívoca e innegable autoridad que le da haberse tomado el poema primero y el género gauchesco después, en saludable y talentísima joda. Algo habrá hecho (bien) para que esto suceda (Saturaín, Inodoro Pereyra, 8).

Sin embargo, la versión abandona el humor y la ironía y se convierte en un homenaje, otro más, al gaucho más universal, trasladando toda la intensidad dramática a las viñetas: «Me interesó la propuesta de Ediciones de la Flor, porque era la oportunidad de realizar ilustraciones a una página, sin la obligatoriedad del humor. Además, Fierro tiene muchísima acción y me permitía un tratamiento visual tipo historieta de aventuras seria.» (Fontanarrosa, Entrevista La Nación 2007).
Las treinta y seis ilustraciones eran originales en blanco y negro a los que posteriormente se les añadió color digital. Esta adaptación ha tenido varias ediciones e incluso ha sido publicada en fascículos por el periódico Clarín. Estamos ante una nueva visión del gaucho a principios del siglo XXI.

Pocos años después, con el ilustrador muy enfermo, se emprende la última evolución de la adaptación gauchesca en viñetas. De las páginas de Hernández, a través de la interpretación de Fontanarrosa, se llega a una versión animada para el cine. En 2007 se estrena Martín Fierro, más conocida como Fierro con la dirección de Norman Ruiz y Liliana Romero y el guion de Horacio Grimberg con aportaciones también de Fontanarrosa. Las treinta y seis viñetas de la adaptación original en viñetas, se convierten en ciento treinta cinco diseños, que luego serán animados por sesenta dibujantes que harán unas sesenta mil ilustraciones para la animación tradicional de los más de cien personajes que aparecen en la película. Al igual que la anterior adaptación, esta es una obra enfocada a todos los públicos, que se aleja de la concepción infantil de los dibujos animados: "¿Sabés qué pasa? Creo que pesaba sobre la película y la producción, Patoruzito o películas eminentemente para niños. Pero Martín Fierro, lo tomes por donde lo tomes, es un drama. Un drama gaucho. Y son personajes medio intocables. Es un dibujo animado no estrictamente para chicos.» (Fontanarrosa, Entrevista Clarín 2006).

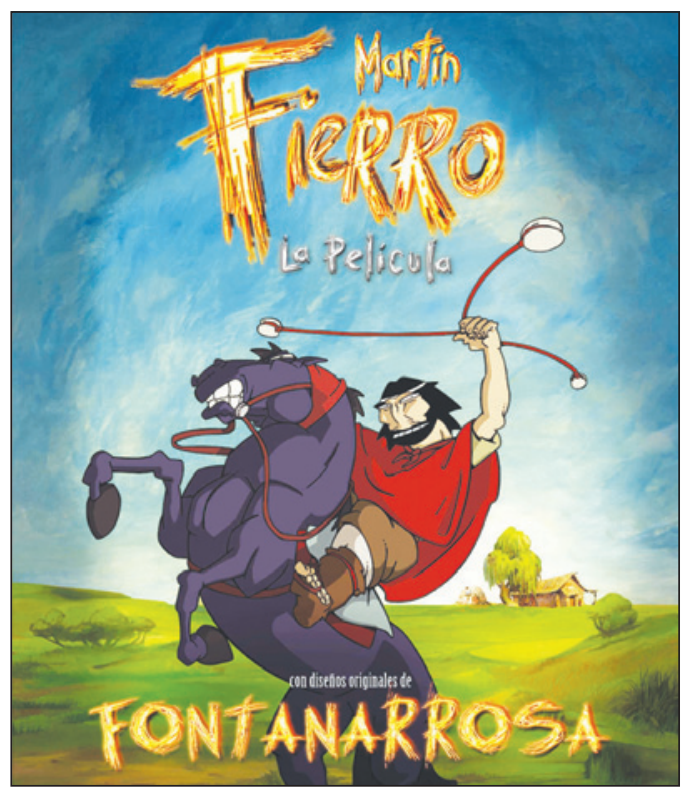

Portada película Martín Fierro 2007. 
Existen otras adaptaciones al cine de acción real, como Martín Fierro (1968) y Martín Fierro, el ave solitaria (2006), pero esta se convierte en una de las de mayor éxito. Aunque no es un portal oficial de la misma, podemos acceder a través de repositorios como Youtube [https://www.youtube.com/ watch?v=om_wrWchxoI]. Se presenta como Martín Fierro (por Fontanarrosa) y tiene más de doscientas mil reproducciones en menos de dos años. Además, en los más de doscientos comentarios podemos ver como la obra sigue siendo un clásico imprescindible y se plantean distintas opiniones sobre lo acertado de la adaptación. Hernández y Cantisani (2014) hacen un pormenorizado análisis de la animación cinematográfica a través de las propuestas de José Paz Gago:

Desde sus inicios ya opta por solo una parte de la historia en pos de resaltar las hazañas del héroe. Decide mostrarnos al personaje desde su entorno, desde afuera, para no solo revivir a Fierro sino también una época que habla por sí misma. Los tiempos de la narración se modifican para atrapar al espectador de cine desde un lenguaje que acota los tiempos para el desarrollo del relato. Finalmente, aprovechando la característica visual del séptimo arte, se recurre a la animación para su expresión sumada a los dibujos de Fontanarrosa que ya poseen valor en sí mismos (Hernández y Cantisano, 160).

Gracias a estas últimas adaptaciones, el autor de «el renegáu» también termina ligado al gaucho más universal a través de las viñetas y el cine:

Por fin. Particularmente me gusta la posibilidad de volver a dibujar con más libertad con la que uno trabaja en los chistes. Me gusta salir del tamaño y de la obligatoriedad del globito. Cuando me tentaron con el libro me intimidaban los antecesores que lo habían retratado: Juan Castagnino, Roberto Páez. Cuando me convocaron para la película, quedé encantado. Ya había tenido propuestas de dibujos animados, pero en definitiva jamás se llevaron a cabo. De cualquier manera, confieso que para mí técnicamente es un terreno desconocido. Me animó el poder participar del guion, porque estamos hablando del Martín Fierro que es intimidante. No por nada le llaman la Biblia gaucha. Había que tener cuidado al pensar la historia: ¡No vaya a ser cosa que uno desate una guerra santa con los defensores del Martín Fierro! (Fontanarrosa, Entrevista Clarín 2006)

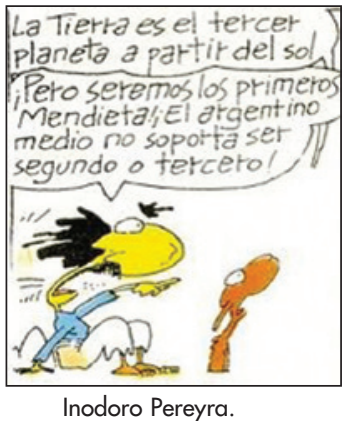

La figura del gaucho sigue teniendo una relevancia fundamental en la identidad argentina gracias a las adaptaciones en historietas que nos transmiten su gran carga icónica y representan la conformación de una tradición fundamental en el mundo del cómic.

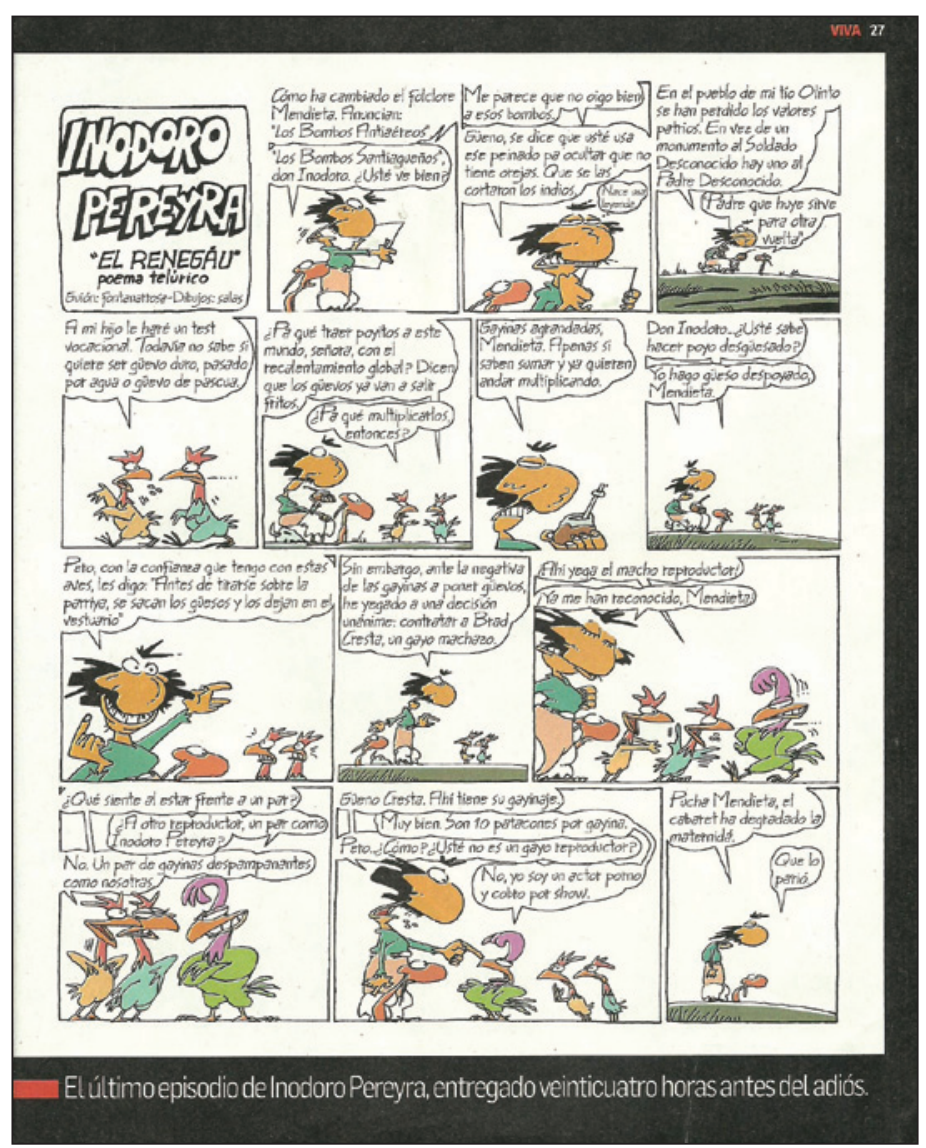

Último episodio Inodoro Pereyra.

\section{Bibliografía}

Alén, Guillermo. «Inodoro Pereyra: una gauchesca de la posmodernidad», en $I X$ Congreso Argentino de Hispanistas, La Plata, Argentina, 2010. [En línea] http:// www.memoria.fahce.unlp.edu.ar/trab eventos/ev.1022/ev.1022.pdf.
La figura del gaucho en la historieta argentina. De las versiones del Martín Fierro a Inodoro Pereyra J. MIQUEL ROVIRA-COLLADO 
Barcia, Pedro Luis. «Introducción», en Portal de Literatura Gauchesca. Biblioteca Virtual Miguel de Cervantes [En línea] http:// www.cervantesvirtual.com/portales/literatura_gauchesca/.

Barrero, Manuel. Entrevista a Carlos Trillo en Tebeosfera [Web], 2002. [En línea] http:// www.tebeosfera.com/1/Documento/Entrevista/Trillo/1.htm.

Calvo, Laura. Comentario sobre la edición Martín Fierro, Argentina, 2003 http:// www.editorial-coiron.com.ar/fierro.htm.

Carril, Bonifacio del. El gaucho a través de la iconografía, Buenos Aires: Emecé, 1978.

De Majo, Óscar. Historieta argentina. La primera mitad de la historia en Tebeosfera, 2008. [En línea] http://www.tebeosfera.com/ documentos/documentos/historieta_argentina_la_primera_mitad_de_la_historia.html.

Fontanarrosa, Roberto. «El Martín Fierro es un drama gaucho». Entrevista de Marina Zucchi Clarín. 10 agosto 2006. [En línea] http://edant.clarin.com/diario/2006/10/08/ espectaculos/c-01211.htm.

Fontanarrosa, Roberto. "Martín Fierro, del dibujo al cine». Entrevista Heriberto Fiorillo, La Nación. 25 agosto 2007. [En línea] http://www.lanacion.com.ar/936856-martin-fierro-del-dibujo-al-cine.

Gezzio, Willian. «Santos Cruz, La historia de un personaje que cambió de nombre y apellido», en Mundo dibujado [Blog], 2012. [En línea] http://mundodibujado.blogspot. com.es/2012/11/santos-cruz.html.

Hernández, Carolina y Cantisani Rovasio, María Luz. «Animando un clásico: Martín Fierro, del libro a la película», en La Animación y las otras Artes. Actas del III Foro Internacional sobre Animación ANIMA, 2013: Págs. 153-161. [En línea] http://www.animafestival.com.ar/forum/ files/2015/01/10_hernandez_cantisani.pdf.

Lozada, Juliana María. Las Ediciones Ilustradas del Martín Fierro. Investigación bibliográfica. Buenos Aires: Museo de Arte Popular José Hernández, 2012. [En línea] http://www.buenosaires.gob. ar/sites/gcaba/files/las-ed-ilust-delmf-06-12-2012.pdf.

Markstein, Don. «The Red Gaucho», en Toonopedia, 2011. [En línea] http://www. toonopedia.com/rgaucho.htm. historieta argentina. Martín Fierro a Inodoro Pereyra

JOSÉ ROVIRA-COLLADO J. MIQUEL ROVIRA-COLLADO

Masotta, Óscar. La historieta en el mundo moderno, Barcelona: Ediciones Paidós, 1982.
Massaroli, José Juan Moreria en Jose Massaroli [blog], 2013. [En línea] http://josemassaroli.blogspot.com.ar/p/juan-moreira.html.

Mollo, Santiago. «SuperHéroes Argentinos (Creados y Escritos por Extranjeros)», en Comivortex, 2013. [En línea] http://comicsvortex.com/superheroes-argentinoscreados-y-escritos-por-extranjeros/.

Rivera, Jorge B. La primitiva literatura gauchesca, Buenos Aires: Editorial Jorge Álvarez, 1968.

Rosales, Luis. «Martín Fierro dibujado por el peruano Paco Cisneros», en Top-Comics [blog], 2011. [En línea] https://luisalberto941.wordpress.com/2011/11/10/ martin-fierro-dibujado-por-el-peruanopaco-cisneros/.

Salas, Jorge. «El proceso de legitimación de la figura del gaucho a través de la historieta y el humor», 2010. [En línea] http:// www.vinetas-sueltas.com.ar/congreso/ pdf/HumorGrafico, GauchescayTradicio $\mathrm{n} /$ salas.pdf.

Sasturain, Juan. El domicilio de la aventura, Buenos Aires: Ed. Colihue, 1995.

Sasturain, Juan. «Una gauchada de Fontanarrosa», en Fontanarrosa, Roberto, Inodoro Pereyra, Buenos Aires: Biblioteca Clarín, 2004: págs. 8-13.

Souto, Luz. «La transgresión del género gauchesco y su importancia en el imaginario nacional argentino», en Sònia Boadas Cabarrocas, Félix Ernesto Chávez, Daniel García Vicens (coord.). La tinta en la clepsidra: fuentes, historia y tradición en la literatura hispánica, Promociones y Publicaciones Universitarias, PPU, 2012: págs. 619-628.

Tiempo Argentino. «El gaucho Martín Fierro, según las ilustraciones de artistas españoles», en Tiempo Argentino, 2011. [En línea] http://tiempoargentino.com/ nota/123910/el-gaucho-martin-fierro-segun-las-ilustraciones-de-artistas-espanoles.

Trillo, Carlos y Saccomano, Guillermo. Historia de la Historieta Argentina, Argentina: Récord, 1980.

Urrero, Guzmán. «El Gaucho, de Hugo Pratt y Milo Manara», en The Cult, 2009. [En línea] http://www.thecult.es/Comic/ HUGO-PRATT-El-Gaucho.html.
Fecha de recepción: 30/07/2015

Fecha de aceptación: 15/10/2015 